\title{
Indigenous use of mistletoes in tropical and temperate region of Nepal
}

\begin{abstract}
R. M. Kunwar ${ }^{1}$, N. Adhikari ${ }^{1}$ and M. P. Devkota ${ }^{2}$
Eleven species of mistletoes are widely used by different ethnic groups of Nepal for various purposes. The local people of the present study areas (one each at tropical and temperate region) were found using eight species of mistletoes for food, fodder and medicine. Noticeable use of the mistletoes is for healing bone fractures, dislocation and sprain.
\end{abstract}

Keywords: Indigenous use, mistletoes, Nepal.

$\mathbf{M}$

istletoes are one of the important components of biodiversity. They play a vital role in natural plant communities by interacting with other hosts, herbivores and dispersers. In many cultures, mistletoes have been a source for many concepts, symbols, and rituals. Since early days, they have been one of the most magical, mysterious and scared plants of folklore. Probably due to their parasitic nature, elusive method of dispersal, and strange growth habit, many cultures have revered, feared, or thought them to have magical properties. The species not only adorn festive as portrait of friendship, but are still respected palliative for the most feared diseases including cancer, with their connotations in sympathetic medicines of abnormal growth (Polhill and Wiens 1998).

In Nepal, mistletoes have traditionally been used since long. However, they have remained unused by the modern pharmacological practices. The indigenous use of mistletoes such as Dendrophthoe falcata, Viscum album and $V$. articulatum was first documented in Nepal in 'Medicinal Plants of Nepal' (HMGN 1970) marking the beginning of ethnobotanical studies on mistletoes. Nonetheless the works on indigenous uses still remained unattained. Present study, therefore, aimed to collate and enumerate the indigenous uses of mistletoes.

\section{Methods}

Primary data on indigenous uses of mistletoes were collected from participatory observations and informal discussions with the locals at Hattikhal, Chepangghat, Deurali and Mulghat area (250-700 m; tropical zone) of Bardia district in April 2003 and in
Godawari-Phulchoki area (1500-2700 m; subtropical and temperate zone) of Lalitpur district in July 2003 to June 2004. Literatures briefing the indigenous use of mistletoes were also reviewed and analyzed.

\section{Results}

Of the eight species found to be used indigenously Dendrophthoe falcata, Scurrula elata, S. pulverulenta and $V$ iscum articulatum were used in Bardia district and Helixanthera ligustrina, Loranthus odoratus, Scurrula elata, S. parasitica, S. pulverulenta, Viscum album and $V$. articulatum in Godawari-Phulchoki area of Lalitpur district. Most of the species were used for healing and curing the bone fractures, dislocation and sprain. Very few were reported as fodder and edible (Table 1). Local people from both areas denied using mistletoes for fuelwood/firewood because they believed that such uses cause them debt in home and eye problems. The use of mistletoes for trapping bird was also important. Tamang ethnic groups of Phulchoki area believed that the use of mistletoes infected Urtica dioca wood brings good luck during gambling.

\section{Discussion}

To date, total of 19 species of the mistletoes are found in Nepal (Devkota 2005). Though the species are few in number, their uses have been practiced indigenously for centuries. Of the 19 species, 11 species are being indigenously used for various purposes.

Most of the existing ethnobotanical reports of Nepal have recorded the importance of mistletoes for rural life. Such importances include medicine, fodder and

\footnotetext{
${ }^{1}$ Centre for Biological Conservation, Kathmandu, NEPAL (ripu@wlink.com.np)

${ }^{2}$ Amrit Campus, Tribhuvan University, Kathmandu, NEPAL
} 
Table 1. Indigenous Use of Mistletoes in Nepal

\begin{tabular}{|c|c|c|c|}
\hline SNo & Species Name & Local Name & Indigenous Use \\
\hline 1 & $\begin{array}{l}\text { Dendrophthoe falcata (L.f.) Etting.* } \\
\text { \{Loranthus bicolor Roxb., } \\
\text { L. falcatus L.f., L. longiflorus Desr. }\end{array}$ & $\begin{array}{l}\text { Rhiniya-M, Ainjeru-N, Mandargon banda-S, } \\
\text { Nihi-T }\end{array}$ & Edible, medicinal \\
\hline 2 & $\begin{array}{l}\text { Helixanthera ligustrina (Wall.) Danser* } \\
\text { \{Loranthus ligustrinus Wall. }\}\end{array}$ & Bhringe-G, Ainjheru-Mg, Ainjeru, Lisso-N & Edible, medicinal \\
\hline 3 & $\begin{array}{l}\text { Loranthus odoratus Wall.* } \\
\{\text { Hyphaer odoratum (Wall.) Danser }\}\end{array}$ & Ainjeru-N, Khik-R, Donglanais- $\mathrm{T}$ & Fodder, medicinal \\
\hline 4 & $\begin{array}{l}\text { Macrosolen cochinchinensis Tiegh. } \\
\text { \{Loranthus cochinchinensis Tiegh., } \\
\text { L. globosus Roxb., L. viridiflorus Wall.\} }\end{array}$ & Ainjeru-N & Medicinal \\
\hline 5 & $\begin{array}{l}\text { Scurrula elata (Edgew.) Danser* } \\
\{\text { Loranthus elatus Edgew. }\}\end{array}$ & Bhringe-G, Ainjeru-N, Ainjera, Che-S, Nai-T & $\begin{array}{l}\text { Edible, fodder, } \\
\text { medicinal }\end{array}$ \\
\hline 6 & $\begin{array}{l}\text { Scurrula parasitica L.* } \\
\{\text { Loranthus scurrula L. }\}\end{array}$ & Ainjeru, Lisso-N & Edible, fodder \\
\hline 7 & $\begin{array}{l}\text { Scurrula pulverulenta (Wall) G. Don* } \\
\text { \{Loranthus carnosus Wall., } \\
\text { L. pulverulentus Wall. }\}\end{array}$ & Bhringe-G, Ainjeru-N & $\begin{array}{l}\text { Edible, fodder, } \\
\text { medicinal }\end{array}$ \\
\hline 8 & $\begin{array}{l}\text { Taxillus vestitus (Wall.) Danser } \\
\{\text { Loranthus vestitus (Wall.) Danser }\}\end{array}$ & Lisso-N & Edible, medicinal \\
\hline 9 & $\begin{array}{l}\text { Viscum album } \mathrm{L} . * \\
\{\text { Viscum costatum, } \\
\text { V. stellatum } \mathrm{D} . \text { Don }\}\end{array}$ & $\begin{array}{l}\text { Ainjeru-C, Mistletoes, Devil's fuge, Birdlime-E, } \\
\text { Harjor-G, Ainjeru, Harchur, Hadjoda, } \\
\text { Sanohatchur-N, Harchu-Ne, Gandhamadini, } \\
\text { Jiwantika-Sa, Nai-T, Bang-Th }\end{array}$ & Edible, medicinal \\
\hline 10 & $\begin{array}{l}\text { Viscum articulatum Burm. f.* } \\
\{\text { Viscum dichotomum } \text { D. Don, } \\
\text { V. liquidambaricolum (Hayata) R.S. Rao }\}\end{array}$ & $\begin{array}{l}\text { Hadachur, Hadjod-N, Harchu-Ne, Bojha-R, } \\
\text { Kathkomunjga-S, Gandhmadini-Sa }\end{array}$ & Fodder, medicinal \\
\hline 11 & Viscum sp. & Lisso-N & Medicinal \\
\hline
\end{tabular}

Source: Field survey (2003 and 2004)* species used in study area, species given in \{\} are synonyms

$\mathrm{C}=$ Chepang, $\mathrm{E}=$ English, $\mathrm{G}=$ Gurung, $\mathrm{M}=$ Moosahar, $\mathrm{Mg}=$ Magar, $\mathrm{N}=$ Nepali, $\mathrm{Ne}=$ Newari, $\mathrm{R}=\mathrm{Rai}, \mathrm{S}=$ Satar,

$\mathrm{Sa}=$ Sanskrit, $\mathrm{Sh}=$ Sherpa, $\mathrm{T}=$ Tamang, $\mathrm{Th}=$ Tharu

food. Besides these, few species are used in trapping birds and few others are for food for birds and butterflies. Mistletoes are extensively applied for curing muscular swelling, sprains, fractures, dislocations, etc. A detailed review of indigenous use of 11 mistletoes species has been presented below for the feaders. Their synonyms and local names are given in table 1.

1. Dendrophthoe falcata (L.f.) Etting. (Loranthaceae) Leaf paste is used in skin diseases. It is taken in abortion (Bhattarai 1991; Siwakoti and Siwakoti 2000). Bark juice/decoction is employed for menstrual problems and asthma (Bohora 1998; Sapkota 2000; Pandey 2001; Bhattarai 2002). Its paste is applied on boils, setting dislocated bones and extracting pus (Manandhar 2002). Fruit is taken as flavor, edible (HMGN 1982; Panthi and Chaudhary 2002; Shrestha and Kunwar 2003), astringent, narcotics, and for curing wounds (Siwakoti and Varma 1996, 1999), and its paste is applied on fractures for setting bones (Manandhar 1986,
1990) and other medicinal purposes (Sah et al 2002). Nectar is food for Hair Crested Drungo and Sunbirds (BPP 1995). Leaf along with Urtica doica (Sisnu) are made into paste and used to treat bone fractures (Bhattarai 1993).

\section{Helixanthera ligustrina (Wall.) Danser (Loranthaceae)}

Fruits are edible (Manandhar 2002) and whole plant is used as medicine (Panthi and Chaudhary 2002; Shrestha and Kunwar 2003).

\section{Loranthus odoratus Wall. (Loranthaceae)} Plant is used as fodder (Gurung 2003). Ripen fruits are taken by Tamang people for indigestion (Manandhar 1991, 2002). In winter, fruits are collected, boiled with equal volume of water and the viscous gel is applied over the tree branches for bird trapping (Devkota 1995; Nepal 1999).

4. Macrosolen cochinchinensis (Lour.) van Tiegh. (Loranthaceae)

Plant is taken to cure headache (Devkota 1997). 
5. Scurrula elata (Edgew.) Danser (Loranthaceae) Leaves are used as fodder. Fruits are edible and used for bird trapping (Shrestha 1988a; Shrestha 1988b; Nepal 1999; Duwadee and Kunwar 2001, Manandhar 2002).

\section{Scurrula parasitica L. (Loranthaceae)}

Leaves are used as fodder. Fruits are edible (Manandhar 2002; Shrestha and Kunwar 2003). If taken, the tender shoots cause loss of appetite and vomiting to livestock (Shrestha 1985).

7. Scurrula pulverulenta (Wall.) G. Don (Loranthaceae)

Leaves are used as fodder. Fruits are edible and used for bird trapping. Stem bark is boiled in water and used as a treatment of jaundice.

8. Taxillus vestitus (Wall.) Danser (Loranthaceae) Plant is boiled and its extract is applied on sprain (Manandhar 1993). It is also used as a wild food plant (Manandhar 1997).

\section{Viscum album Linn. (Viscaceae)}

Fruits are edible, laxative, tonic, aphrodisiac, cardiotonic (HMGN 1970; IUCN 2004); used for tumor, mixed with egg and eaten to cure fracture (Devkota 1997); food for butterfly Delais aglaia (Red base Jazebel), Delais belladona (Hill Jazebel); twigs are used by witch doctors (Khanal and Bhandary 1982). Plant is used as diuretic; applied in wounds, earache, and enlargement of spleen (Malla 1994; Khan 1997; Joshi and Joshi 2001; Panthi and Chaudhary 2002; IUCN 2004). Root extract is taken to cure titanus (Dangol 2002) and bark paste is applied on muscular swelling, boils, wounds, sprains, fractures (Manandhar 1992; Shrestha and Dhillion 2003; Panthi and Chaudhary 2004; Poudel and Uprety 2004). Plant paste is applied on curing dislocated bones (Coburn 1984; Manandhar 1989a; Oli 2001; Prasai 2001; Shrestha et al 2004), wounds of cattle (Manandhar 1989 a,b; Shrestha 1997; Bhattarai 2002; Shrestha et al 2004; IUCN 2004) and abdomen swelling.

10. Viscum articulatum Burm.f. (Viscaceae)

Plant bark is often mixed with hen egg and Pinus roxburgbii leaf and taken for ailment of bone dislocation. It is given in fever attended with itching limbs and as an aphrodisiac. It has febrifuge properties (HMGN 1970). Paste prepared from all parts of the plant is applied over the fractured portion of the body (Oli 2003).
Stem paste and decoction is applied on cuts, wounds, bone fracture (Nepal 1999; Joshi and Joshi 2001; Niraula 2001; Gurung 2003; IUCN 2004), ulcers and blood diseases (Sapkota 2000; Pandey 2001; IUCN 2004), epilepsy and sprain (Siwakoti and Siwakoti 2000). Plant is also used as fodder (Thapa et al 1997).

\section{Viscum sp. (Viscaceae)}

Plant paste is used in fracture (Kattel and Kurmi 2004).

\section{Acknowledgements}

First author is grateful to Zoological Society of London, UK; and Natural History Museum, Kathmandu for providing support to have field visit in Bardia district. The second author is thankful to University Grant Commission, Kathmandu Nepal.

\section{References}

Bhattarai, G. P. 2002. Diversity and indigenous uses of flowering plant resources in the Churiya forests of Parsa Wildlife Reserve and adjoining area. Central Department of Botany, Tribhuvan University, Nepal. M.Sc. Thesis. 110.

Bhattarai, N. K. 1991. Folk herbal medicines of Makawanpur district, Nepal. International journal of pharmacognosy, 29(4): 284-295.

Bhattarai, N. K. 1993. Folk herbal medicines of Dolakha district, Nepal. Fitoterapia, 64(5): 387-395.

Bohora, G. B. 1998. A study of traditional medicinal plants and its knowledge among people of Bajhang district, Nepal. Central Department of Social Science, Tribhuvan University, Nepal. M.Sc. Thesis. 33.

BPP. 1995. Biodiversity assessment of Terai wetlands. HMG Nepal and Government of Netherlands. BPP technical publication no. 1. 80+.

Coburn, B. 1984. Some native medicinal plants of western Gurungs. Kailash, 55-87.

Dangol, N. 2002. Documentation of the ethnobotanical knowledge of Kumal community of Chitwan district, central Nepal. Central Department of Botany, Tribhuvan University, Nepal. M.Sc. Thesis. 99.

Devkota, M. P. 1997. Mistletoes of Khimti forest, Ramechaap district, Nepal. Banko janakari 7(2): 52-53.

Devkota, M. P. and Acharya, N. 1995. Status of angiospermic tree parasites of Kathmandu valley. (A report) WWF Nepal program. 19. 
Devkota, M. P. 2005. Biology of mistletoes and their status in Nepal Himalaya. Himalayan journal of sciences, 3(5): 85-88.

Duwadee, N. P. S and Kunwar, R. M. 2001. Botanical survey of Khaptad National Park and buffer zone area, far western Nepal. Botanica orientalis, 2: 165170.

Gurung, K. 2003. Indigenous knowledge on the plant resources used by the people of Tinjure area, Terhathum district, Nepal. Botanica orientalis, 3: 118-125.

Hara, H., Chater, A. O. and Williams, L. H. J. 1982. An enumeration of flowering plants of Nepal. Vol. III. British Museum (Natural History), London. 226.

HMGN. 1970. Medicinal plants of Nepal. Bulletin of the department of medicinal plants No. 3 . Department of Plant Resources, MoFSC, Kathmandu, Nepal. 153.

HMGN. 1982. Wild edible plants of Nepal. Bulletin of department of medicinal plants No. 9. Department of Plant Resources, MoFSC, Kathmandu, Nepal. 285.

IUCN. 2004. National register of medicinal and aromatic plants. IUCN, Kathmandu, Nepal. 202.

Joshi, K. K. and Joshi, S. D. 2001. Genetic heritage of medicinal and aromatic plants of Nepal Himalaya. Buddha academic publishers and distributors, Kathmandu, Nepal. 239.

Kattel, L. P. and Kurmi, P. P. 2004. A study on plant used by traditional herbal healers in mid west and eastern Nepal. Plant resources, Department of Plant Resources, Kathmandu, Nepal. 16-21.

Khan, M. H. 1997. Documentation of indigenous knowledge in Chepang community of Shaktikhor village, Chitwan district, Nepal. In Proceeding of the national workshop in Nepal: Ethnobotany for conservation and community development (eds) Shrestha K. K., Jha P. K., Shengji P., Rastogi A., Rajbhandary S. and Joshi M. Ethnobotanical Society of Nepal, Kathmandu, Nepal.

Khanal, B. and Bhandary, H. 1982. Food plants of some butterfly larvae. Journal of natural history museum, 6(1-4): 57-70.

Malla, S. B. 1994. Medicinal herbs in the Bagmati zone, ADPI distribution series no. 8. Kathmandu, Nepal, ICIMOD. 85.

Manandhar, N. P. 1986. A contribution to the ethnobotany of Mushar tribes of Dhanusa district, Nepal. Journal of natural history museum, 10(1-4): 53-64.
Manandhar, N. P. 1989a. Medicinal plants used by the Chepang tribes of Makawanpur district Nepal. Fitoterapia, 60(1): 61-68.

Manandhar, N. P. 1989b. Ethnoveterinary medicinal drugs of central development region of Nepal. Bulletin medico ethnobotanical research, 10(3-4): 9399.

Manandhar, N. P. 1990. Traditional phytotherapy of Danuwar tribe of Kamlakhong in Sindhuli district, Nepal. Fitoterapia, 61 (4): 325-332.

Manandhar, N. P. 1991. Medicinal plants-lore of Tamang tribe of Kavrepalanchok district, Nepal. Economic botany, 45:58-71.

Manandhar, N. P. 1992. Folklore medicine of Dhading district, Nepal. Fitoterapia, 63(2): 163177.

Manandhar, N. P. 1993. Ethnobotanical note on folk lore remedies of Baglung district Nepal. Contribution to the Nepalese studies, 20(2): 183-196.

Manandhar, N. P. 1997. Unreported wild food plants of Nepal. Ethnobotany, 9: 97-100.

Manandhar, N. P. 2002. Plants and people of Nepal. Timbre Press, Oregon, USA. 599.

Nepal, M. 1999. Ethnobotany of Rai and Sherpa community in the Makalu Barun conservation area, eastern Nepal. Central Department of Botany, Tribhuvan University, Nepal. M.Sc. Thesis. 150.

Niraula, K. 2001. Vegetation analysis and ecology of the medicinal plants in and around Tinjure hill (Terhathum and Sankhuwasabha districts), eastern Nepal. Central Department of Botany, Tribhuvan University, Nepal. M.Sc. Thesis. 103.

Oli, B. R. 2001. Local knowledge on plant utilization among the major ethnic communities (Limbu, Rai, Brabmin, Cheetri, Magar, and Tamang) in the eastern Churia, Nepal. Central Department of Botany, Tribhuvan University, Nepal. M.Sc. Thesis. 137.

Oli, B. R. 2003. Ethnomedicinal uses of plants among the Limbus of Hellock area of Tpethok VDC, Taplejung district, Nepal. Botanica orientalis, 3:112115.

Pandey, B. 2001. Ethnobotany in human welfare: a case study for Bhujung, Lamjung, Nepal. Department of Biological and Environmental Science, Kathmandu University, Nepal. M.Sc. Thesis. 126.

Panthi, M. P. and Chaudhary, R. P. 2002. Angiosperm flora of Arghakhanchi district and adjoining areas, West Nepal. Journal of natural history museum, 21(14): 7-32. 
Panthi, M. P. and Chaudhary, R.P. 2003. Ethnomedicinal plant resources of Arghakhanchi district, Nepal. Ethnobotany, 15: 71-86

Polhill, R. and Wiens, D. 1998. Mistletoes of Africa. The Royal Botanical Garden, Kew. 60.

Poudel, R. C. and Uprety, Y. 2004. Ethnobotanical and NTFP survey in Nuwakot district, Nepal. Botanica orientalis, 4:66-71.

Prasai, A. 2001. Indigenous management of NTFPs: its role in sustainable development. Central Department Sociology/Anthropology, Tribhuvan University, Nepal. M.A. Thesis. 89.

Sah, J. P., Singh, R. L. and Bhatta, N. 2002. Floristic diversity and use of plants in Ghodaghodi lake area, Nepal. Journal of natural history museum, 21(14): $243-266$.

Sapkota, P. P. 2000. Ecological study and traditional uses of Medicinal plants in Malika forest Baglung, west Nepal. Central Department of Botany, Tribhuvan University, Nepal. M.Sc. Thesis. 95.

Shrestha, A, KC, B., and Thapa, C. B. 2004. Ethnomedicinal uses of plants among the Kumal community in Chirtundhara, Palpa district, Nepal. Botanica orientalis, 4: 59-62.

Shrestha, A. K. 1997. Documentation of indigenous knowledge on the utilization of plant resources by the Tharu community around RBNP, West Nepal. Central Department of Botany, Tribhuvan University, Nepal. M.Sc Thesis.

Shrestha, K. and Kunwar, R. M. 2003. Plants. In Oliver S (ed.) Babai river valley: fish and biodiversity survey, Royal Bardia National Park, Nepal. ZSL conservation report no.3. London: The Zoological Society of London. 119.

Shrestha, K. K., Rajbhandary S., Tiwari, N., Poudel R. C. and Uprety Y. 2004. Ethnobotany in Nepal:
Review and perspectives. (A report) WWF Nepal program and Ethnobotanical Society of Nepal, Kathmandu, Nepal. 271.

Shrestha, P. 1985. Research note: contribution to the ethnobotany of the Palpa area. Contribution to the Nepalese studies, 12(2): 63-74.

Shrestha, P. M and Dhillion S. S. 2003. Medicinal plant diversity and use in the highlands of Dolakha district, Nepal. Journal of Ethnopharmacology, 86: 81-96.

Shrestha, P. 1988a. Ethnobotanical observation on the Tamangs of Kathmandu valley, In Proceeding of national conference on science and technology, Royal Nepal Academy of Science and Technology, Kathmandu, Nepal. 353-358.

Shrestha, P. 1988b. Contribution to the ethnobotany of the Tamangs of Kathmandu valley. Contribution to the Nepalese studies, 15(2): 247-266.

Siwakoti, M. and Siwakoti, S. 2000. Ethnobotanical uses of plants among the Satar tribes of Nepal. In Ethnobotany and medicinal plants of Indian subcontinent (ed) Maheswori J. K. Scientific publishers, Jodhpur, India. 79-108.

Siwakoti, M. and Varma, S. K. 1996. Medicinal plant of the Terai of east Nepal. Jnl eco. taxon. bot. Additional series- 12. Scientific publication, Jodhpur, India. 423-438.

Siwakoti, M. and Varma, S. K. 1999. Plant diversity of eastern Nepal: flora of plains of eastern Nepal. M/S Bishen Singh Mahendra Pal Singh, Dehra Dun, India. 491.

Thapa, B., Walker D. H. and Sinclair F. L. 1997. Indigenous knowledge of the feeding value of tree fodder. Animal feed science and technology, 67: 97-114. 